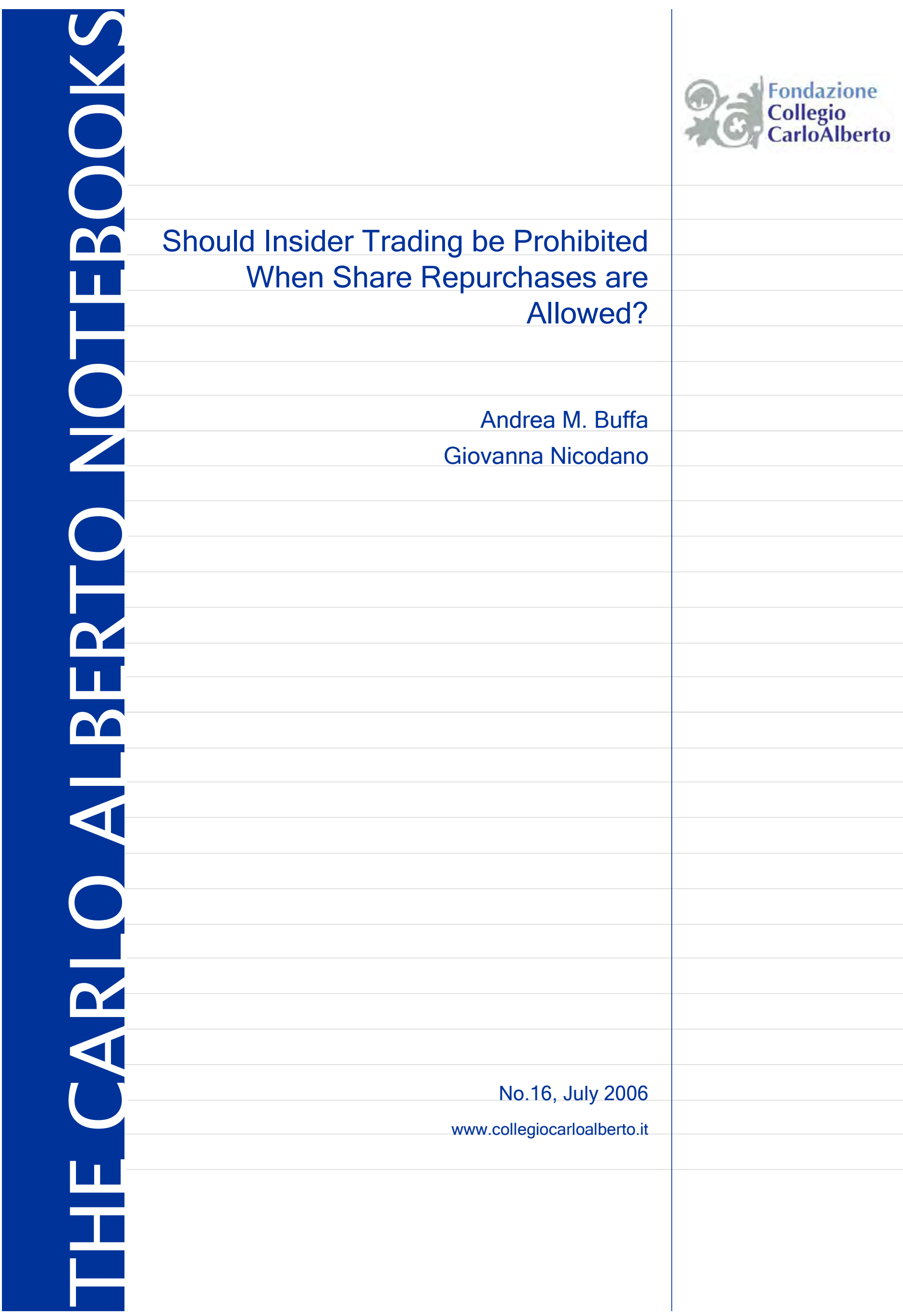




\title{
Should Insider Trading be Prohibited when Share Repurchases are Allowed?
}

\author{
ANDREA M. BUFFA* GIOVANNA NICODANO ${ }^{\dagger}$
}

July 2006

${ }^{*}$ Center for Research on Pension and Welfare Policies (CeRP).

${ }^{\dagger}$ Università degli Studi di Torino and Fondazione Collegio Carlo Alberto.

We got useful comments from Larry Glosten, Paolo Bertoletti, Sudipto Bhattacharya, Arnoud Boot, Riccardo Calcagno, Giovanni Cespa, Michael Fishman, Henry Hultquist, Hayne Leland, Stefano Lovo, Henry Manne, Francesco Sangiorgi and seminar participants at Bocconi, IGIER, Società Italiana degli Economisti, Studienzentrum Gerzensee and Fondazione Collegio Carlo Alberto. The usual disclaimer applies.

(C) 2006 by Andrea M. Buffa and Giovanna Nicodano. Any opinions expressed here are those of the authors and not those of the Fondazione Collegio Carlo Alberto. 


\begin{abstract}
This paper considers share repurchases as the way long-term shareholders preserve their ability to use corporate information for speculative purposes when insider trading regulation is enforced. This use of corporate information increases the adverse selection losses of short-term shareholders. Thus, buy-back programs reduce their incentive to invest in stocks that back the most productive technology, leading to a socially inefficient equilibrium. It follows that insider trading should not be banned when share repurchases are allowed.
\end{abstract}

JEL classification: G18, G14, D82, K22

Keywords: insider trading, share repurchase, liquidity, securities regulation, corporate information 


\section{Introduction}

The legal arguments for a ban on insider trading are converging to the view that inside information is a property of the corporation and insider trading is akin to theft (Bhattacharya and Daouk, 2002). Economists (King and Roëll, 1988; Dow and Rahi, 2003; Easterbrook and Fischel, 1991) also contend that insider traders misappropriate corporate property because the insiders profit from information even though they do not have property rights over it. Consistent with this view, this paper models inside information as a corporate asset which is used by the firm. It may thus choose to disclose information to market participants or to keep it secret. Moreover, the company may perform open market share repurchases in order to correct misvaluation. We study these alternative corporate information policies, in the polar cases when insider trading is legal or is effectively prohibited on misappropriation grounds, so as to assess the benefits of insider trading regulation ${ }^{1}$.

The existing literature finds that insider trading should be regulated when the adverse selection losses caused to investors in the stock market exceed improvements in firm interim investment choice (Bernhardt, Hollifield and Hughson, 1995; Leland, 1992) or in risk sharing among investors (Bhattacharya and Nicodano, 2001) brought about by insider trading. In order to single out the incremental contribution of our model, we do not consider these potential sources of benefits, as there is neither interim investment nor risk aversion. Hence insider trading should reduce welfare, and its regulation be beneficial. On the contrary, we show that banning insider trading is welfare diminishing.

Indeed long term shareholders, who are assumed to be in control of corporate policies and to observe inside information, would trade on it when insider trading is unrestricted. This is mostly profitable to them when the company refrains from both repurchasing shares and disclosing information to the market, implying that these become the corporate information policies when no regulation discourages insider trading. The equilibrium policy shifts instead to stock repurchases when insider trading is effectively banned. Share repurchases become the way long-term shareholders preserve their ability to use corporate information so as to maximize the value of their stockholdings. But this new allocation of corporate information worsens the welfare of the short-term shareholders, who suffer from adverse selection losses when trading in the marketplace: their losses increase because the firm is a monopolist information trader that maximizes both its trading profits and the negative external-

\footnotetext{
${ }^{1}$ U.S. courts increasingly rely on the misappropriation theory to decide insider trading cases (Lehn, 1989). This holds that an individual violates Rule $10 b-5$ of the 1934 Securities and Exchange Act if he or she knowingly trades on information that is used without the consent of its source.
} 
ity on market liquidity. Thus open-market share repurchases reduce their incentive to invest in stocks that back the most productive technology, leading to a socially inefficient equilibrium. It follows that insider trading should not be banned when open market share repurchases are allowed.

Clearly, a ban on such information-based share repurchase coupled with insider trading restrictions would improve on welfare, by eliminating all sources of adverse selection and preserving short-term traders' incentives to invest in stocks. However, we observe that such restrictions cannot be supported on misappropriation grounds, as the firm is making profits out of stock mispricing on behalf of all shareholders. Furthermore, share repurchase (SR) programs are usually not banned in the real world, and their use is instead spreading, as regulators recognize that they may be useful for substituting cash dividend payouts, modifying capital structure, implementing stock option plans and providing price stabilization ${ }^{2}$. While acknowledging these objectives for SR, regulators explicitly recognize and worry about the "privileged informational position of the issuer" when share repurchase programs are implemented (see OICV-IOSCO, 2004, p.10-12). Other indicators support our focus on firms' superior information when repurchasing shares. Firstly, it has been found that firms usually repurchase stock in order to take advantage of potential undervaluation (Dittmar, 2000) and that there are significant positive abnormal returns several years after repurchase announcements (Ikenberry et al, 1995; Mitchell and Stafford, 2000). Secondly, Barclay and Smith (1988) find wider bid ask spreads for firms planning and announcing share repurchases, implying that market liquidity worsens. Last but not least, Brockman and Chung (2001) show that the adverse selection component of the bid-ask spread increases substantially during repurchase periods, consistent with the hypothesis of information-based buy-backs.

In our model we focus on share repurchase performed through open market trading by the company. This is the most common mechanism used by companies because it gives them flexibility as to the timing, price and size of repurchases ${ }^{3}$. The term "stock repurchase" indicates in the model both the buying and the selling of own shares by the company. Indeed only a few jurisdictions, including the U.S., treat the selling of repurchased shares as a new distribution subject to a prospectus offering or require cancellation of repurchased shares. Several others permit an issuer to sell its own shares held "in treasury" before, during, and after a stock repurchase plan (OICV-IOSCO, 2004, p.7,8,9).

\footnotetext{
${ }^{2}$ See OICV-IOSCO (2004, p.3). The relative importance of these goals are debated in a large empirical literature, see Dittmar (2000) and Grullon and Michaely (2004) as well as references therein.

${ }^{3}$ Stephens and Weisbach (1998) report that they constitute $90 \%$ of total repurchases performed in the U.S..Studies of alternative mechanisms include Brennan and Thakor (1990) analysis of self tender offers and Peyer and Vermaelen's (2005) empirical investigation of privately negotiated SR.
} 
Our argument for unrestricted insider trading hinges on larger losses hitting shortterm shareholders when the firm repurchases shares. This argument does not hold only for companies with diffuse ownership ${ }^{4}$. In such firms, profits from share repurchases are almost entirely paid back to short-term shareholders, thus causing them little loss. Moreover, insiders are too few to compete very aggressively relative to the case of the monopolist firm.

For all other companies, one way to reduce adverse selection losses is disclosure of inside information by the firm. However, disclosure in our setting is never a corporate policy, unless we drop the realistic assumption that long-term shareholders determine corporate choices ${ }^{5}$. With mandated disclosure our conclusion that insider trading should be unregulated when open market share repuchase are allowed holds true, unless announcements occur without delays. Mandated disclosure should not be associated with insider trading regulation as information-based open-market share repurchases would again substitute for insider trading, increasing short-term shareholders losses.

Our paper thus delivers new insights by considering insider trading, stock repurchases and disclosure as competing uses of corporate information. This new approach straddles three branches of research. Earlier literature on information production and dissemination acknlowledges that valuable information is produced by firms and could voluntarily be disclosed (Diamond, 1985; Fishman and Hagerty,1989). It further suggests that intermediaries have an incentive to sell or trade on information (Allen, 1989, 1990; Admati and Pfleiderer, 1986, 1988a). But it does not consider inside information as a corporate asset, and the associated opportunity for firms themselves to trade and sell on inside information ${ }^{6}$.

Seminal papers on share repurchases treat them as an alternative to dividends for paying out corporate profits (Miller and Modigliani, 1961; Bhattacharya, 1979). Barclay and Smith (1988) consider that they can generate adverse selection costs in the stock market. However, in their model share repurchase programs are still considered as a distribution policy rather than a corporate information policy ${ }^{7}$. Re-

\footnotetext{
${ }^{4}$ These do not seem to be common outside Anglo-saxon countries, as companies - especially smaller ones - usually have concentrated ownership (see Becht et al., 2002, and references therein)

${ }^{5}$ Independent board members, that represent non-controlling shareholders' preferences, are typically a minority. Moreover, their appointment by controlling shareholders often weakens their incentives to vote against them. Similarly, short-term shareholders do not usually participate in shareholders' meetings. See Becht, Bolton and Roell, 2002

${ }^{6} \mathrm{~A}$ previous version of this paper, available from the authors upon request, analyzes the case of corporate information sales which is sidestepped here for simplicity.

${ }^{7}$ Brennan and Thakor (1990) make a related point. They observe that repurchases oblige shareholders to trade in order to obtain a desired level of dividends. In doing so, smaller less informed
} 
cently, Oded (2005) shows that a firm can signal its value to the market by simply announcing share repurchases because it can buy back in the future conditional on its information. In this paper we take these information-based repurchases as given, and ask what they imply for insider trading regulation.

Finally, an insider trader is not appropriating a corporate asset in the insider trading literature. He is often depicted as an agent with lower costs of information acquisition than financial analysts (Fishman and Hagerty, 1992) and, more generally, better information than his trading counterparts (Kyle, 1985). Sometimes she is a corporate insider, as in Huddart, Hughes and Levine (2001), John and Narayanan (1997) and Medrano and Vives (2004), but only in the sense that she is subject to regulation imposing disclosure of her trades and accordingly changes her trading strategy. In one case the insider is explicitly misappropriating corporate information (Manove, 1989) but no alternative use of inside information by the company is allowed for. Khanna et al. (1994) implicitly assume that inside information is a corporate asset, by allowing the controlling shareholder to implicitly sell inside information to a manager for insider trading purposes. They also emphasize that short-term shareholders anticipate their adverse selection losses when deciding whether to invest in the risky asset, as we do. However, they study the interplay of financial analysis, insider trading and production, while we emphasize the link between insider trading, stock repurchases and disclosure.

Another feature of our paper is the conflict of interest between controlling shareholders and short-term shareholders, which is affected by insider trading regulation. The analysis in Maug (2002) also connects the conflict of interest between types of shareholders to insider trading legislation - specifically tippee liability. He argues that managers of underperforming companies collude against small shareholders with dominant shareholders, who give up their monitoring role in favour of insider trading when this is unrestricted. He suggests that there is instead alignment of all shareholders' incentives when a ban is enacted, because this prevents managers from tipping dominant blockholders about worsening firm profitability. By considering the case of information-based share repurchases, we highlight that such an alignment need not hold.

A key insight, driving our result on welfare reducing insider trading regulation, is that a monopolistic information trader minimizes the leakage of information through prices. This is due to Admati and Pfleiderer (1988), by whom we also borrow the modelling of the trading subgame. In a dynamic setting, Holden and Subrahmanyam (1992) analysis supports their results. On the contrary Back, Cao and Willard (2000)

shareholders run the risk of partial expropriation by better informed shareholders who prefer repurchases over cash distribution. 
argue that this is not the case when traders' signals are diverse, as they will trade less aggressively recognizing their incentive to reduce competition. In the case of insiders, however, the signal of the traders will be (close to) perfectly correlated, leading to the same type of insight obtained in the static setting.

The rest of this paper is organized as follows. Section 2 presents the model. Section 3 describes the equilibrium allocation and the welfare analysis. Section 4 examines alternative securities regulations. In Section 5 we conclude.

\section{The Model}

There are two types of agents: long-term investors and liquidity traders. At time 0, they can store their unit endowment, with no depreciation. Alternatively, they can become shareholders by investing it in a risky, long-term technology with expected return $\bar{q}>1$. In what follows we denote with $n^{*}\left(m^{*}\right)$ the number of long-term investors (liquidity traders) and with $n(m)$ the number of investors who become long-term shareholders (liquidity shareholders). Let's finally define $N^{*}=m^{*}+n^{*}$ and $N=m+n$ as the total number of investors and shareholders, respectively.

Liquidity traders, $m^{*}>1$, know that they will be hit by an endowment shock in the future: if they invest in the risky technology at time 0 , they will inelastically supply (or demand) an unknown amount of shares at time 2. These investors are similar to the "discretionary" liquidity traders of Admati and Pfleiderer (1988b). They have discretion only ex-ante, in choosing whether to invest their endowment at positive return and bear future trading costs or store it with zero net return. On the contrary, long-term shareholders, who will manage the company and observe inside information, will be able to trade shares only if it pays them to. They can also decide whether to trade on inside information, provided that insider trading regulation is not enforced. So, let's define $j(c)$ as the number of insider traders conditional on insider trading regulation, where the variable $c$ indicates whether that regulation is enforced $(c=1)$ or not $(c=0)$ :

$$
j(c)=\left\{\begin{array}{lll}
\in[0, n] & \text { if } & c=0 \\
0 & \text { if } & c=1
\end{array}\right.
$$

In our setting corporate assets include inside information. This is a noisy signal $q+\vartheta$ of liquidation value, which is costlessly produced within the firm between $t=1$ and $t=2$, where $q \sim \mathcal{N}\left(\bar{q}, \sigma_{q}^{2}\right), \vartheta \sim \mathcal{N}\left(0, \sigma_{\vartheta}^{2}\right)$ and $\operatorname{Cov}(q, \vartheta)=0$. Hence, long-term shareholders must decide the corporate information policy ${ }^{8}$. The policy set, $\mathcal{C P}$, is

\footnotetext{
${ }^{8}$ Within this setting we do not have to face any delegation problem, which, instead, may arise if
} 
Table 1: Classification of corporate policies

\begin{tabular}{|c|c|}
\hline$c p=\{0,0\}:$ & secrecy \\
\hline$c p=\{1,0\}:$ & open-market share repurchases \\
\hline$c p=\{0, \bar{d}\}:$ & disclosure \\
\hline$c p=\{1, \bar{d}\}:$ & disclosure and open-market share repurchases \\
\hline
\end{tabular}

a finite set of four elements defined by two components: $c p=\{k, d\}$. The first one defines whether the company carries out open-market share repurchases $(k=1)$, thus becoming an informed speculator. The second one indicates truthful disclosure to the market $(d=\bar{d})$ or secrecy $(d=0)$. In case of disclosure, we assume that the signal can be costlessly transmitted to the public, who know the distribution of payoffs and signals and hence the reliability of information. However, we also assume that there exists a strictly positive probability, $1-\bar{d}$, that liquidity shocks are realized before disclosure. This is because time necessarily elapses between information production and its transmission - at least the time for preparing the public statement ${ }^{9}$. As a consequence, the choice between disclosure and secrecy turns out to be equivalent to the choice between the two probabilities. A classification of corporate policies is summarized in Table 1.

At time 2, inside information is distributed according to previous decisions and asset trading takes place. The sequence of events is summarized in Table 2 .

\subsection{The trading subgame}

In this section we determine equilibrium stock price, $P$, and the value of a right to trade on inside information, $\pi$, conditional on corporate information policy. We start by addressing the case when corporate information does not reach the market through a public announcement before trading occurs.

liquidity shareholders had the majority. Thus, as in Brennan and Thakor (1990), we avoid relying on an arbitrarily assumed objective function of a manager. In our model this would be a useless complication, since our focus is not managerial incentives, as in Fischer (1992).

${ }^{9}$ We are not referring here to postponements decided by the firm for strategic reasons, such as those related to proprietary information, but to technical delays. 
Table 2: Sequence of events

Time 0: $\quad n^{*}$ long-term and $m^{*}$ liquidity investors invest their unit endowment either in the risky technology, with expected return $\bar{q}>1$, or in the risk-free asset.

Time 1: Long-term shareholders choose the allocation of rights over inside information, through corporate policy decision.

Time 2: Corporate policy is carried out, liquidity shocks are realized and stock trading takes place.

Time 3: Risky technology return, $q$, is realized and distributed together with profits from stock repurchases.

The trading structure is as follows. Risk-neutral speculators can borrow at zero interest rate and submit orders to a market-maker, who also receives price-inelastic orders from liquidity shareholders. As in Admati and Pfleiderer (1988a), the marketmaker infers information from the order flow and prices the security so as to obtain zero expected profits. In such a setting a rational speculator enters the market only when he is better informed than the market-maker (AP, 1988a, p.98). In our model this is the case only for long-term shareholders and for the company.

Let $x=\beta(q+\vartheta-\bar{q})$, where $\beta$ is a constant to be determined, be the orders submitted by an informed speculator who maximizes his expected trading profits given his information. Each liquidity trader submits a market order $\xi_{i} \sim \mathcal{N}\left(0, \sigma_{\xi}^{2}\right)$, which is i.i.d across $i$ and independent from other random variables. Net liquidity orders are equal to $z$, where $\sigma_{z}^{2}=m \sigma_{\xi}^{2}$. The market-maker sets a price equal to the expected liquidation value conditional on his information, which consists of inference from the total order flow $\omega$ and of corporate information released by the company. The total order flow $\omega$ is the sum of the orders placed by the liquidity traders, the company $(k \in\{0,1\})$ and the $j(c)$ insiders:

$$
\begin{aligned}
\omega & =z+(k+j(c)) x \\
& =z+(k+j(c)) \beta(q+\vartheta-\bar{q})
\end{aligned}
$$

The price set by the market-maker is given by:

$$
P=E(q \mid \omega)=\bar{q}+\lambda \omega
$$

where $\lambda$ is a non-stochastic constant to be determined. The unique linear Nash 
equilibrium is found by following the same steps as AP (1988a, p.99). The equilibrium coefficients are equal to:

$$
\begin{aligned}
\beta & =\left[\frac{\sigma_{z}^{2}}{(k+j(c))\left(\sigma_{q}^{2}+\sigma_{\vartheta}^{2}\right)}\right]^{\frac{1}{2}} \\
\lambda & =\frac{(k+j(c)) \beta \sigma_{q}^{2}}{(k+j(c)+1) \sigma_{z}^{2}}
\end{aligned}
$$

Equation (5) shows that the responsiveness of price to the order flow is directly proportional to (i) the intensity of informed traders' reaction to their private signal, $(k+j(c)) \beta$; (ii) the relative responsiveness of the order flow to both asset liquidation value and liquidity shocks, as summarized by the ratio $\sigma_{q}^{2} / \sigma_{z}^{2}$. The parameter $\lambda$ is Kyle's (1985) measure of market illiquidity.

We can now determine the value to a risk-neutral speculator of the right to trade on inside information. This is equal to the expected difference in profits from trading with and without such information. But no-information profits are nil: in fact, only speculators who are better informed than the market-maker trade. We therefore obtain:

$$
\pi=\mathrm{E}\left[\max _{x} \mathrm{E}[(q-P) x \mid q+\vartheta]\right]
$$

where price depends on $x$ as shown by Equations (2) and (3). Using Equations (2) - (5), the equilibrium value of the right for one speculator, when information is not disclosed to the market prior to trading, is equal to:

$$
\begin{aligned}
\pi(k+j(c), m)= & \beta \frac{\sigma_{q}^{2}}{k+j(c)+1} \\
= & {\left[\frac{m \sigma_{\xi}^{2}}{(k+j(c))\left(\sigma_{q}^{2}+\sigma_{\vartheta}^{2}\right)}\right]^{\frac{1}{2}}\left(\frac{\sigma_{q}^{2}}{k+j(c)+1}\right) } \\
= & \frac{\alpha m^{\frac{1}{2}}}{\sqrt{k+j(c)}(k+j(c)+1)} \\
& \text { where } \quad \alpha \equiv\left[\frac{\sigma_{\xi}^{2}\left(\sigma_{q}^{2}\right)^{2}}{\left(\sigma_{q}^{2}+\sigma_{\vartheta}^{2}\right)}\right]^{\frac{1}{2}}
\end{aligned}
$$

This value falls if the variance of liquidity trading is lower, because the marketmaker is able to make more precise inference from the order flow. It is inversely related 
to $(k+j(c))$ in that competitive speculators do not restrict their orders enough so as to prevent more information to leak through the order flow. Indeed, it is also true that the total value of trading profits to speculators, $(k+j(c)) \pi(k+j(c), m)$, decreases as their number, $(k+j(c))$, grows.

If information reaches the market before trading occurs, then the market maker is informed as the speculators, who therefore decide not to enter the market. It follows that the right to trade on information has no value.

Hence, the ex-ante value of the right to trade for a speculator before corporate policy is chosen is equal to $(1-d) \pi$. In fact we get back to Equation (7) if corporate information policy is secrecy. If the firm chooses a disclosure policy, instead, profits will be reduced to $(1-\bar{d}) \pi$, where $\bar{d}$ is the probability that announcement happen before trading.

\subsection{The allocation of inside information by the company}

We now turn to the allocation of inside information that the shareholders elect at time 1. Since long-term shareholders hold the majority, they will choose that corporate policy $(c p \in \mathcal{C P})$ that maximizes their expected payoff, and then each shareholder will receive a share $1 / N$ of corporate profits. In order to compute shareholders' payoffs in different scenarios, we determine corporate distributions that are associated to each information allocation.

LEMma 1: The per-share profit deriving from corporate information policy, $\varphi(k)$, is equal to:

$$
\varphi(k)=\left\{\begin{array}{lll}
0 & \text { if } & k=0 \\
\frac{(1-d) \pi(1+j(c), m)}{N} & \text { if } & k=1
\end{array}\right.
$$

Profits from corporate policy are positive only if the company trades on its private information. Therefore, if open-market stock repurchases is corporate policy, total receipts are equal to trading profits when there are $1+j(c)$ information traders competing in the market, i.e. the company and $j(c)$ insider traders. These are then distributed to the $N$ shareholders.

\subsection{Ex-ante investment choice}

The value of corporate information to each long-term shareholder, who is also an insider trader, is non-negative under any corporate information policy. Indeed, he 
gets trading profits from both corporate share repurchases and insider trading (when this is unregulated). Thus, each long-term shareholder expected payoff, conditional on investing in the risky asset, turns out to be:

$$
\mathrm{E}_{r}\left(W_{L}\right)=\bar{q}+(1-d)[\pi(k+j(c), m)(1-c)]+\varphi(k)
$$

From Equation (9) it is straightforward to see that the expected payoff to a long-term shareholder is never less than one, which is the payoff of storing the unit endowment. This is the reason why all long-term investors become shareholders of the risky technology. Thus, $n=n^{*}$.

Short-term investors (liquidity traders) may instead suffer from adverse selection losses coming from either open-market stock repurchases or insider trading or both, the more, the lower is market liquidity. Since the market-maker obtains zero profits, expected trading gains to informed speculators equal expected losses by liquidity traders. Hence, each liquidity shareholder's expected payoff conditional on holding one unit of the risky technology (denoted by subscript $r$ ) must be calculated net of $L($ ), expected per-capita trading losses diminished by profits from corporate information trading.

$$
\mathrm{E}_{r}\left(W_{S}\right)=\bar{q}-L(k, d, j(c), m)
$$

where

$$
L(k, d, j(c), m)=(1-d) \pi(k+j(c), m)\left[\frac{(k+j(c))}{m}\right]-\varphi(k)
$$

Therefore, in order to invest in the risky technology, short-term investors' expected payoff must be no lower than one, which is the investors' expected payoff conditional on storing the unit endowment:

$$
\bar{q}-1>L(k, d, j(c), m)
$$

If this inequality is not satisfied, they do not enter the stock market $(m=0)$ and consequently there is underinvestment $\left(N<N^{*}\right)$ in the risky technology.

Finally, expected aggregate welfare is defined as the weighted sum of the investors' unconditional expected payoffs:

$$
\mathrm{E}(W) \equiv n^{*} \mathrm{E}\left(W_{L}\right)+m^{*} \mathrm{E}\left(W_{S}\right)
$$




\section{Equilibrium and Welfare Analysis}

\subsection{Insider trading regulation not enforced}

In this Subsection we solve the model, assuming that insider trading regulation is not enforced in the market $(c=0)$. So, we have to find which corporate policy is chosen at time 1, knowing that every long-term shareholder can potentially become an insider trader.

Proposition 1: If insider trading regulation is not enforced, the equilibrium corporate policy is secrecy, $c p^{*}=\{0,0\}$. Every long-term shareholder becomes insider trader, $j(0)=n^{*}$, and the number of short-term shareholders is equal to

$$
m=\left\{\begin{array}{lll}
m^{*} & \text { if } & \bar{q}-1>L\left(0,0, n^{*}, m^{*}\right) \\
0 & \text { otherwise }
\end{array}\right.
$$

Proof: See the Appendix.

We present here the logic of Proposition 1. Since corporate policy is chosen by long-term shareholders, they try to minimize the revelation of private information to the market. Hence, disclosure is always dominated by secrecy. Moreover, insider traders would obtain a higher payoff, with respect to the equilibrium one, if they acted cooperatively, that is if they chose to both refrain from insider trading and carry out open-market stock repurchases. In this way, they would exploit the advantage of one monopolistic information trader, who minimizes the leakage of information through prices, as in Admati and Pfleiderer (1988). However, the strategy no insider trading associated to open-market stock repurchases as corporate policy is not a credible one, thus causing the equilibrium strategy to be insider trading. This being the case, they prefer to choose secrecy as corporate policy, because the benefits from a lower competition in the market more than compensate the costs from not receiving any profit from share repurchases. Finally, liquidity traders invest in the risky asset if and only if the expected excess return compensates their adverse selection losses.

REMARK 1: We are assuming that shareholders' meetings choose share repurchases. This is the case in European countries. However - in certain jurisdictions including the U.S. - a decision of the board is sufficient. It is easy to show that equilibria do not change when a subset of long-term shareholders choose on behalf of others as well. 


\section{$3.2 \quad$ Insider trading regulation enforced}

Let's consider now the case in which misappropriation of corporate information is banned $(c=1)$. This means that, if enforcement is perfect, there are no insider traders, $j(1)=0$.

Proposition 2: If insider trading regulation is enforced, the equilibrium corporate policy is open-market stock repurchases, $c p^{*}=\{1,0\}$. Moreover, the number of shortterm shareholders is equal to

$$
m=\left\{\begin{array}{lll}
m^{*} & \text { if } & \bar{q}-1>L\left(1,0,0, m^{*}\right) \\
0 & \text { otherwise }
\end{array}\right.
$$

Proof: See the Appendix.

In this case insider trading regulation prevents long-term shareholders from using individually their private information for speculative purposes. However, the regulation paradoxically make it possible for them to collude with each other by carrying out open-market repurchases. The stock market is therefore characterized by a single speculator, that is the company. Finally, liquidity traders choose to invest in the risky technology if and only if their adverse selection losses are compensated by the expected excess return.

\subsection{Welfare comparison}

In order to evaluate the effectiveness of insider trading regulation, we must compare expected aggregate welfare with and without insider trading regulation.

LEMMA 2: The equilibrium expected aggregate welfare turns out to be

$$
\mathrm{E}(W)=n^{*} \bar{q}+m^{*}+\operatorname{Pr}\left(m=m^{*}\right) \cdot m^{*}(\bar{q}-1)
$$

where $\operatorname{Pr}\left(m=m^{*}\right)$ is a degenerate probability.

Proof: See the Appendix.

The first best level of welfare, $N^{*} \bar{q}$, is reached if all investors enter the stock market. This ensures that all endowments are invested in the risky technology, which dominates the riskless one $(\bar{q}>1)$. Trading losses to one type of trader do not matter for social welfare as they are offset by gains to the others. Hence, for a welfare comparison we need first to order short-term investors' expected losses, $L\left(0,0, n^{*}, m^{*}\right)$ and $L\left(1,0,0, m^{*}\right)$. 
Proposition 3: Let's define $\mu \equiv m^{*} / N^{*}$. Assume that $\mu<\mu^{\prime}$. Then liquidity traders' expected loss is lower if insider trading regulation is not enforced. Symmetrically, expected aggregate welfare is higher under no ban on misappropriation.

Proof: See the Appendix.

Results concerning aggregate welfare can best be understood by focusing on three different levels of the risky asset excess return.

$(\overline{\mathbf{q}}-\mathbf{1})>\mathbf{L}\left(\mathbf{1}, \mathbf{0}, \mathbf{0}, \mathbf{m}^{*}\right)$ If the excess return is very high, then liquidity traders are more than compensated for adverse selection losses and so they invest in the risky asset, irrespective of the insider trading regulation.

$(\overline{\mathbf{q}}-\mathbf{1})<\mathbf{L}\left(\mathbf{0}, \mathbf{0}, \mathbf{n}^{*}, \mathbf{m}^{*}\right)$ If the excess return is very low, then liquidity traders do not receive enough compensation from investing in the risky asset, irrespective of the insider trading regulation. Also in this case, the costless ban on insider trading is useless since it does not lead to any increase in the expected aggregate welfare.

$\mathbf{L}\left(\mathbf{0}, \mathbf{0}, \mathbf{n}^{*}, \mathbf{m}^{*}\right)<(\overline{\mathbf{q}}-\mathbf{1})<\mathbf{L}\left(\mathbf{1}, \mathbf{0}, \mathbf{0}, \mathbf{m}^{*}\right)$ In this case liquidity traders' investment decision changes according to the enforcement of insider trading regulation. In particular, without regulation, liquidity traders are still compensated enough for adverse selection losses. They invest their endowments in the risky technology and consequently the market is characterized by the highest level of expected aggregate welfare (first best). On the contrary, insider trading regulation induces liquidity traders not to enter the market. This is so because the lower leakage of information through prices, due to a monopolistic use of private information by the company increases liquidity traders losses. Therefore, insider trading regulation imposes an underinvestment cost, equal to $m^{*}(\bar{q}-1)$, and lowers expected aggregate welfare.

The boundaries of the last region are portrayed in Figure 5. The region widens as both the variance of the liquidity shocks and the precision of inside information increase, because a monopolistic trader is better able to exploit both relative to competing insiders.

For insider trading regulation to reduce welfare, the proportion of liquidity shareholders must not exceed a certain threshold $\left(\mu^{\prime}\right)$. The reason is that profits from SR are paid out to all shareholders. The larger their relative number, the larger their share of these profits. In the limit, all their trading losses would be paid back to them if they owned $100 \%$ of shares, in which case they would prefer SR to insider trading. The threshold we are mentioning is increasing in $n^{*}$ (see the Appendix). The reason is that more competition among insiders leads to lower trading losses to liquidity investors. In order to appreciate this restriction, consider the case of small firms (i.e. 
$\left.N^{*}=30\right)$. Then $m^{*} / N^{*}$ should not exceed $50 \%$. However, for middle-size companies $\left(N^{*}=543\right), m^{*} / N^{*}$ can be as large as 80.67 , and for very large firms $\left(N^{*}=1066\right)$ the threshold is 84.53 . Thus, insider trading regulation may be beneficial only for companies with widely diffuse ownership.

According to Proposition 3, the answer to the question "should insider trading be prohibited when share repurchases are allowed?" is negative. The first two columns of Table 3, which presents the equilibrium expected aggregate welfare and information allocation, clearly show this result. This is so because insider trading regulation turns out to be the instrument to make insider traders commitment to collude with each other credible. Information-based open-market stock repurchases turn out to be as the institutionalized way to create monopolistic insider profits. For this reason liquidity traders, who are the crucial players for achieving full investment in the market, prefer to be the trading counterpart of competing insider traders rather than of a monopolistic one.

\section{Expanding Securities Regulation}

Below we investigate whether other types of securities regulation may solve the underinvestment problem associated with adverse selection.

\subsection{Ban on share repurchases}

We first consider the introduction of a ban on open-market share repurchases. This implies that the parameter $k$ is exogenously set to zero, so that long-term shareholders can only choose $d$.

Proposition 4: If insider trading regulation is not enforced, a ban on open-market stock repurchases is never welfare improving. Secrecy is the equilibrium corporate policy, $c p^{*}=\{0,0\}$, every long-term shareholder becomes insider trader, $j(0)=n^{*}$ and the number of short-term shareholders is equal to

$$
m=\left\{\begin{array}{lll}
m^{*} & \text { if } & \bar{q}-1>L\left(0,0, n^{*}, m^{*}\right) \\
0 & \text { otherwise }
\end{array}\right.
$$

Proof: According to Proposition 1, long-term shareholders would choose $k^{*}=0$ if insider trading regulation is not enforced. Thus, imposing it through regulation does not alter the outcome of the equilibrium without insider trading regulation. Q.E.D. 
As shown by the third column in Table 3, a stock repurchase regulation is useless. It is not able to increase expected aggregate welfare by reducing underinvestment in the risky asset.

Let's now consider the scenario in which insider trading and share repurchase regulations are implemented together.

PROPOSITION 5: If both insider trading and open-market repurchases regulations are enforced, secrecy or disclosure can both be equilibrium corporate policies, $c p^{*}=\{0, d\}$. Liquidity traders always invest in the risky technology, $m=m^{*}$. The first best is attained for every level of the risky return.

Proof: A multiple equilibrium arises because long-term shareholder are indifferent between secrecy and disclosure if they can not exploit corporate private information for speculative purpose. Since the double regulation neutralize all the potential speculators (by both insider traders and the company), liquidity traders' adverse selection losses collapse to zero. The last part of the proposition is obtained through straightforward algebra.

Q.E.D.

This proposition connects our study to earlier analyses of insider trading, which do not consider adverse selection losses from stock repurchases. In our setting there are no benefits from insider trading, hence regulating it turns out to be welfare efficient. However this scenario without share repurchases is not realistic, as discussed in the introduction, because they are allowed for several reasons, such as substituting cash dividend payouts, modifying capital structure and reducing price volatility.

\subsection{Mandated disclosure}

Last but not least, we consider the introduction of a mandatory disclosure. This implies that the parameter $d$ is exogenously set to $\bar{d}$, so that long-term shareholders can only choose whether to carry out open-market repurchases.

Proposition 6: If disclosure is mandatory but insider trading regulation is not enforced, long-term shareholders choose not to carry out open-market share repurchases, $c p^{*}=\{0, \bar{d}\}$. All of them become insider traders, $j(0)=n^{*}$, and the number of shortterm shareholders is equal to

$$
m=\left\{\begin{array}{lll}
m^{*} & \text { if } & \bar{q}-1>L\left(0, \bar{d}, n^{*}, m^{*}\right) \\
0 & \text { otherwise }
\end{array}\right.
$$

This regulation leads to a welfare improvement. 
Proof: The first part of the proposition is just a particular case of Proposition 1, where now long-term shareholders can not choose $d$. Nevertheless the conclusions are equivalent, as can be easily derived from the Proof of Proposition 1 in Appendix. The second part is instead due to the presence of a positive probability, $\bar{d}$, that corporate information reaches the market before trading takes place. For this reason short-term investors, facing lower expected trading losses, invest in the risky technology for a larger number of values of the risky return.

Q.E.D.

Regulators do recognize that disclosure of price sensitive information "on a full and prompt basis should certainly go some way towards reducing the likelihood that a company will be holding a significant informational advantage [...] while in the course of purchasing its own shares" (OICV-IOSCO, 2004, p.10). The following proposition concerns whether such a policy would benefit from a ban on insider trading.

PROPOSITION 7: If disclosure is mandatory and insider trading regulation is enforced, long-term shareholders choose to carry out open-market share repurchases, $c p^{*}=$ $\{1, \bar{d}\}$. The number of short-term shareholders turns out to be equal to

$$
m=\left\{\begin{array}{lll}
m^{*} & \text { if } & \bar{q}-1>L\left(1, \bar{d}, 0, m^{*}\right) \\
0 & \text { otherwise }
\end{array}\right.
$$

Moreover, if $\mu<\mu^{\prime}$ the combination of the two regulations is always sub-optimal relative to mandated disclosure alone.

Proof: Again the first part of the proposition draws upon the Proof of Proposition 2 in the Appendix. The second part is obtained through straightforward algebra since, as in Proposition 3, it relies on the fact that, under the condition on the proportion of short-term shareholders, liquidity traders' expected loss is higher if insider trading regulation is enforced.

Q.E.D.

Thus a stricter regulation (disclosure plus insider trading regulation) is less effective than a softer one (only mandated disclosure) in raising the investment in the risky technology by liquidity traders, as shown by the last two columns in Table 4 . We can therefore conclude that, even when a disclosure policy is mandatory, insider trading should not be prohibited when open-market share repurchases are allowed.

\section{Discussion and Concluding Remarks}

Bhattacharya and Daouk (2002) wonder why insider trading regulation is not enforced in several countries, even if insider trading appears to raise the cost of capital by $5 \%$. 
We suggest that the increase in the cost of capital might be larger, unless ownership of companies in those countries is widely diffused. Indeed, misappropriation of corporate information by insider traders appears to be welfare increasing in our paper when ownership is concentrated, as firms will otherwise adopt information-based share repurchase programs which increase short-term shareholders' trading losses.

In countries where ownership of companies is concentrated, we highlight that a ban on insider trading may help the financing of companies only if information-based open-market share repurchases are also curbed. This observation, in turn, shows the limitations of the misappropriation theory as a basis for limiting insider trading: the use of privileged information by the issuer is welfare decreasing even if it is not a theft of information.

Our setting deliberately ignores interim investment and risk aversion in order to emphasize the interplay between insider trading and corporate information policy. Including the reaction of firm investment and production to the information content of prices should not change our insights, as insider trading is based on information produced within the firm, hence already embedded in firm real choices. Only if information unknown to managers were disseminated by trading, then it could benefit corporate investment choices - as observed by Leland (1992).

The introduction of risk aversion would reinforce or weaken the result that a ban on insider trading is welfare reducing when SR are allowed, to the extent that information dissemination improves (Bhattacharya and Nicodano, 2001) or worsens (Medrano and Vives, 2004) risk sharing. More importantly, a monopolistic trader such as the issuer - may be able to better distribute risk among shareholders than the uncoordinated shareholders by themselves, as Admati and Pfleiderer (1990) suggest. However, this demanding extension is left for further work. 


\section{Appendix}

Proof of Proposition 1: We can consider a two stage game: in the first stage long-term shareholders choose the corporate policy (policy subgame), in the second one they decide whether to enter the stock market as insider traders (entrance subgames).

To derive the equilibrium corporate policy, $c p^{*}$, let's first consider the four entrance subgames, one for each alternative information allocation. In all entrance subgames the strategic set of each insider trader consists in two strategies: Enter, NotEnter (the market). Here we prove that, whatever is the strategic choice of $n-1$ insiders and the information allocation, the optimal strategy of the $n$-th insider is to Enter the market.

$c p=\{0, d\} \quad$ We analyze first the two subgames associated with either secrecy $(d=0)$ or disclosure $(d=\bar{d})$. Since both a secrecy and a disclosure policies do not provide any profit from share repurchases to shareholders, the strategy NotEnter leads always to a zero payoff, while the strategy Enter guarantees a non-negative payoff. The following payoffs matrix clearly shows that for the $n$-th insider Enter is a dominant strategy, for $m \geqslant 1$. Hence, the Nash equilibrium of these subgames is such that every insider enters the market. Moreover, they obtain $(1-d) \pi\left(n^{*}, m\right)$ as trading profit.

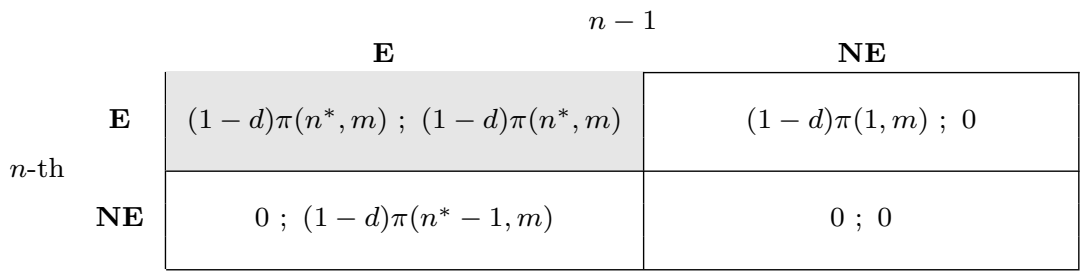

$c p=\{1, d\} \quad$ Next we analyze the case of buy-backs, coupled with either secrecy or disclosure. If share repurchases are part of the corporate information policy, Enter is still a dominant strategy for the $n$-th insider for $m \geqslant 1$. However, since this result is less straightforward than the previous one, let's compare the $n$-th insider's payoffs (given by the sum of distributions of corporate profits from share repurchases and of insider trading profits), associated to the strategies of the other $n-1$ insiders. If the latter decide to enter the market, the strategy Enter is the best response for the $n$-th insider if:

$$
\begin{aligned}
(1-d) \pi\left(1+n^{*}, m\right) \frac{N+1}{N} & >(1-d) \pi\left(n^{*}, m\right) \frac{1}{N} \\
\frac{\sqrt{n^{*}+1}}{\sqrt{n^{*}}\left(n^{*}+1\right)}\left(n^{*}+2\right) & <n^{*}+m+1
\end{aligned}
$$

Let's define the l.h.s. of the above inequality as $F\left(n^{*}\right)$ and the r.h.s as $G\left(n^{*}, m\right)$. Thus, we have to prove that $F\left(n^{*}\right)<G\left(n^{*}, m\right) \quad \forall n^{*}, m \geqslant 1$. Let's consider the following three steps: 
(i) we prove that $F\left(n^{*}\right)<G\left(n^{*}, 1\right) \quad \forall n^{*} \geqslant 1$ :

$$
\begin{aligned}
\frac{\sqrt{n^{*}+1}}{\sqrt{n^{*}\left(n^{*}+1\right)}}\left(n^{*}+2\right) & <n^{*}+2 \\
\frac{1}{\sqrt{n^{*}} \sqrt{n^{*}+1}} & <1
\end{aligned}
$$

which is always true for $n^{*} \geqslant 1$.

(ii) we prove that $G\left(n^{*}, m\right)<G\left(n^{*}, m^{\prime}\right) \quad \forall n^{*} \geqslant 1, m<m^{\prime}$ : straightforward.

(iii) we can conclude that $F\left(n^{*}\right)<G\left(n^{*}, 1\right)<G\left(n^{*}, m\right) \quad \forall n^{*}, m \geqslant 1$.

Since the above inequality is true for every $n \geqslant 1$, then the strategy Enter is still the best response if $n-1$ insiders decide not to enter the market:

$$
(1-d) \pi(2, m) \frac{N+1}{N} \quad>\quad(1-d) \pi(1, m) \frac{1}{N}
$$

\begin{tabular}{|c|c|c|}
\hline & $\mathbf{E}$ & $\mathrm{NE}$ \\
\hline \multirow{2}{*}{$\begin{array}{cc} & \mathbf{E} \\
n \text {-th } & \\
& \mathbf{N E}\end{array}$} & $(1-d) \pi\left(1+n^{*}, m\right) \frac{N+1}{N} ;(1-d) \pi\left(1+n^{*}, m\right) \frac{N+1}{N}$ & $(1-d) \pi(2, m) \frac{N+1}{N} ;(1-d) \pi(2, m) \frac{1}{N}$ \\
\hline & $(1-d) \pi\left(n^{*}, m\right) \frac{1}{N} ;(1-d) \pi\left(n^{*}, m\right) \frac{N+1}{N}$ & $(1-d) \pi(1, m) \frac{1}{N} ;(1-d) \pi(1, m) \frac{1}{N}$ \\
\hline
\end{tabular}

Again, the Nash equilibrium of these subgames is such that every insider enters the market. In this case each obtains $(1-d) \pi\left(1+n^{*}, m\right) \frac{N+1}{N}$ as trading profit.

Finally, in order to determine the equilibrium of the policy subgame, we just need to compare the payoffs associated to the Nash equilibria of the four entrance subgames. It can be seen that $d=\bar{d}$ reduces (or at most leaves unchanged) all payoffs. Hence long-term shareholders choose $d=0$. For this reason we can focus on the remaining corporate policies, secrecy and open-market repurchases. Secrecy is the equilibrium corporate policy if:

$$
\begin{aligned}
\pi\left(n^{*}, m\right) & >\pi\left(1+n^{*}, m\right) \frac{N+1}{N} \\
\frac{\sqrt{n^{*}+1}\left(n^{*}+2\right)}{\sqrt{n^{*}}\left(n^{*}+1\right)} & >\frac{n^{*}+m+1}{n^{*}+m}
\end{aligned}
$$

Let's define the l.h.s. of the above inequality as $F\left(n^{*}\right)$ and the r.h.s as $H\left(n^{*}, m\right)$. Thus, we have to prove that $F\left(n^{*}\right)>H\left(n^{*}, m\right) \quad \forall n^{*}, m \geqslant 1$. As before, let's consider three steps:

(i) we prove that $F\left(n^{*}\right)>H\left(n^{*}, 1\right) \quad \forall n^{*} \geqslant 1$ :

$$
\begin{aligned}
\frac{\sqrt{n^{*}+1}\left(n^{*}+2\right)}{\sqrt{n^{*}}\left(n^{*}+1\right)} & >\frac{n^{*}+2}{n^{*}+1} \\
\sqrt{n^{*}+1} & >\sqrt{n^{*}}
\end{aligned}
$$

which is always true for $n^{*} \geqslant 1$. 
(ii) we prove that $H\left(n^{*}, m\right)>H\left(n^{*}, m^{\prime}\right) \quad \forall n^{*} \geqslant 1, m<m^{\prime}$ :

$$
\frac{\partial H}{\partial m}=-\frac{1}{\left(n^{*}+m\right)^{2}}<0 \quad \forall n^{*}, m \geqslant 1
$$

(iii) we can conclude that $F\left(n^{*}\right)>H\left(n^{*}, 1\right)>H\left(n^{*}, m\right) \quad \forall n^{*}, m \geqslant 1$. Therefore, $c p^{*}=\{0,0\}$.

Turning now to short-term shareholders, it is possible to determine the cutoff value $L\left(0,0, n^{*}, m^{*}\right)$ for the risky technology excess return, given $\left\{n^{*}, m^{*}, c, \sigma_{q}^{2}, \sigma_{\xi}^{2}, \sigma_{\vartheta}^{2}\right\}$. If $(\bar{q}-1)$ exceeds $L\left(0,0, n^{*}, m^{*}\right)$, then there exist an equilibrium characterized by $\{k=0 ; d=0$; $\left.N=N^{*} ; c=0\right\}$. So, the $m^{*}$-th liquidity trader invests in the risky technology if $m^{*}-1 \mathrm{do}$, since excess payoff exceeds expected adverse selection losses coming from insider trading ${ }^{10}$. If, instead, $(\bar{q}-1)$ is lower than $L\left(0,0, n^{*}, m^{*}\right)$, the unique equilibrium is characterized by $\{k=0$; $\left.d=0 ; N=n^{*} ; c=0\right\}$ and there is underinvestment in the stock market $(m=0)$. Q.E.D.

Proof of Proposition 2: Let's consider the same game as before: the policy subgame does not change, while the four entrance subgames disappear. Indeed the strategic set in each entrance subgame is now a singleton because the strategy Enter is eliminated by insider trading regulation. Therefore, the two stage game collapses to the policy subgame, in which long-term shareholders choose the optimal corporate policy.

In order to determine the equilibrium of the policy subgame, $c p^{*}$, we compare the payoffs associated to the four degenerate subgames. If corporate policy is secrecy or disclosure of private information, long-term shareholders gain zero profits, because they "waste" their private information. On the contrary, with share repurchases, they are able to exploit their private signal and per-capita profits from share repurchases are equal to $(1-d) \pi(1, m) \frac{N+1}{N}$. Again, long-term shareholders choose $d=0$ and therefore we conclude that $c p^{*}=\{1,0\}$.

Since the stock market is characterized by no insider trading and open-market share repurchases is the equilibrium corporate policy, liquidity traders' investment decision is driven by the following cutoff value for the risky technology excess return: $L\left(1,0,0, m^{*}\right)$. If $(\bar{q}-1)$ exceeds $L\left(1,0,0, m^{*}\right)$, then there exist an equilibrium ${ }^{11}$ characterized by $\{k=1 ; d=0$; $\left.N=N^{*} ; c=1\right\}$. If, instead, $(\bar{q}-1)$ is lower than $L\left(1,0,0, m^{*}\right)$, the unique equilibrium is characterized by $\left\{k=1 ; d=0 ; N=n^{*} ; c=1\right\}$ and there is underinvestment in the stock market $(m=0)$.

Q.E.D.

Proof of Lemma 2: We first show that, given equilibrium outcomes, $\mathrm{E}(W \mid m)$ is indepen-

\footnotetext{
${ }^{10}$ The equilibrium could be not unique because $L(k, d, j(c), m)$ is decreasing in $m$. Indeed, it does not pay a liquidity trader to invest in the risky technology if others do not even if $\bar{q}-1>$ $L\left(0,0, n^{*}, m^{*}\right)$, unless $\bar{q}-1$ also exceeds $L\left(0,0, n^{*}, 1\right)$. If we add this restriction, this well-known multiplicity problem disappears.

${ }^{11}$ Again, we could have multiple equilibria because $L(k, d, j(c), m)$ is decreasing in $m$. If we add the restriction, $\bar{q}-1>L(1,0,0,1)$, the equilibrium becomes unique.
} 
dent of insider trading regulation.

$$
\begin{aligned}
\mathrm{E}\left(W \mid m=m^{*}\right) & = \begin{cases}n^{*}[\bar{q}+\pi()]+m^{*}\left[\bar{q}-\frac{n^{*}}{m^{*}} \pi()\right]=N^{*} \bar{q} & \text { if } \quad c=0 \\
n^{*}[\bar{q}+\varphi(1)]+m^{*}\left[\bar{q}-\frac{1}{m^{*}} \pi+\varphi(1)\right]=N^{*} \bar{q} & \text { if } \quad c=1\end{cases} \\
\mathrm{E}(W \mid m=0) & =n^{*} \bar{q}+m^{*} \quad \forall c
\end{aligned}
$$

Equations (A9) and (A10) can be rewritten, in compact form, as:

$$
\mathrm{E}(W \mid m)=n^{*} \bar{q}+m^{*}+m(\bar{q}-1) \quad \forall c
$$

Thus, it follows that

$$
\mathrm{E}(W)=n^{*} \bar{q}+m^{*}+\operatorname{Pr}\left(m=m^{*}\right) \cdot m^{*}(\bar{q}-1)
$$

where $\operatorname{Pr}\left(m=m^{*}\right)$ is a degenerate probability since

$$
\operatorname{Pr}\left(m=m^{*}\right)=\operatorname{Pr}(\bar{q}>L()+1)=\{0,1\}
$$

Proof of Proposition 3: The first part of the proposition requires that the following inequality is satisfied,

$$
\begin{aligned}
L\left(0,0, n^{*}, m^{*}\right) & <L\left(1,0,0, m^{*}\right) \\
\pi\left(n^{*}, m^{*}\right)\left(\frac{n^{*}}{m^{*}}\right) & <\pi\left(1, m^{*}\right)\left(\frac{1}{m^{*}}-\frac{1}{N^{*}}\right) \\
\frac{1}{\sqrt{n^{*}}\left(n^{*}+1\right)}\left(\frac{n^{*}}{m^{*}}\right) & <\frac{1}{2}\left(\frac{n^{*}}{m^{*} N^{*}}\right) \\
N^{*} & <\frac{\sqrt{n^{*}\left(n^{*}+1\right)}}{2}
\end{aligned}
$$

Let's first define $f\left(n^{*}\right)=\sqrt{n^{*}}\left(n^{*}+1\right) / 2$. Since we consider only strictly positive values of $n^{*}$, then $f\left(n^{*}\right)$ is invertible in the domain $\mathbb{R}_{++}$:

$$
f^{-1}\left(N^{*}\right)=\frac{(A-1)^{2}}{3 A}
$$

where $A \equiv\left(1+54 N^{* 2}+6 N^{*} \sqrt{3+81 N^{* 2}}\right)^{1 / 3}$. Hence, we can find the maximum proportion of liquidity shareholders $\mu^{\prime}$ such that, for all $\mu<\mu^{\prime}$, the above inequality is satisfied. This value can be expressed a function of $N^{*}$ or $n^{*}$ :

$$
\mu^{\prime} \equiv\left\{\begin{array}{lll}
g\left(N^{*}\right)=1-\frac{f^{-1}\left(N^{*}\right)}{N^{*}} & \text { with } & \frac{\mathrm{d} g}{\mathrm{~d} N^{*}}>0 \\
h\left(n^{*}\right)=1-\frac{n^{*}}{f\left(n^{*}\right)} & \text { with } & \frac{\mathrm{d} h}{\mathrm{~d} n^{*}}>0
\end{array}\right.
$$

The second part of the proposition becomes straightforward once observed that the set $\left\{\bar{q}: \operatorname{Pr}\left(m=m^{*} \mid c=0\right)>\operatorname{Pr}\left(m=m^{*} \mid c=1\right)\right\}$ is non-empty.

Q.E.D. 


\section{References}

[1] Admati A.R. and P. Pfleiderer, 1986, A monopolistic Market for Information, Journal of Economic Theory 39, 400-438.

[2] Admati A.R. and P. Pfleiderer, 1988a, Selling and Trading on Information in Financial Markets, American Economic Review PEYP, 96-103.

[3] Admati A.R. and P. Pfleiderer, 1988b, A Theory of Intraday Patterns: Volume and Price Variability, Review of Financial Studies 1, 3-40.

[4] Allen F., 1989, Information Contracting in Financial Markets, in Bhattacharya S. and G.M. Constantinides eds., Financial Markets and Incomplete Information, Vol.2, Rowman and Littlefield, 188-197.

[5] Allen F., 1990, The Market for Information and the Origin of Financial Intermediation, Journal of Financial Intermediation 1(1), 3-30.

[6] Back K., H. Cao, and G.A. Willard, 2000, Imperfect Competition Among Informed Traders, Journal of Finance 55, 2117-2155.

[7] Barclay M.J. and C.W. Smith, 1988, Corporate Payout Policy: Cash Dividends versus OpenMarket Repurchases, Journal of Financial Economics 22, 61-82.

[8] Becht M., P. Bolton and A. Roell, 2002, Corporate Governance and Control, in G.M. Constantinides, M. Harris and R. Stulz eds., Handbook of the Economics of Finance, North-Holland.

[9] Bernhardt D., B. Hollifield and E. Hughson, 1995, Investment and Insider Trading, Review of Financial Studies 8(2), 501-543.

[10] Bhattacharya S., 1979, Imperfect Information, Dividend Policy, and the "Bird in the Hand Fallacy", Bell Journal of Economics 10, 259-270.

[11] Bhattacharya S. and G. Nicodano, 2001, Insider Trading, Investment and Liquidity: A Welfare Analysis, Journal of Finance 56(3), 1141-1156.

[12] Bhattacharya U. and H. Daouk, 2002, The World Price of Insider Trading, Journal of Finance 57(1), 75-108.

[13] Brennan M.J. and V. Thakor, 1990, Shareholder Preferences and Dividend Policy, Journal of Finance 45(4), 993-1018.

[14] Brockman P. and D.Y. Chung, 2001, Managerial Timing and Corporate Liquidity: Evidence from Actual Share Repurchases, Journal of Financial Economics 61, 417-448.

[15] Diamond D.W., 1985, Optimal Release of Information by Firms, Journal of Finance 40(4), 1071-1093.

[16] Dittmar A.K., 2000, Why do Firms Repurchase Stock?, Journal of Business 73(3), 331-355.

[17] Dow J. and R. Rahi, 2003, Informed Trading, Investment and Welfare, Journal of Business 76(3), 439-454.

[18] Easterbrook F.H. and D.R. Fischel, 1991, The Economic Structure of Corporate Law, Cambridge, MA: Harvard University Press.

[19] Fischer P.E., 1992, Optimal Contracting and Insider Trading Restrictions, Journal of Finance 47(2), 673-694.

[20] Fishman M.J. and K.M. Hagerty, 1989, Disclosure Decisions by Firms and the Competition for Price Efficiency, Journal of Finance 44(3), 633-646. 
[21] Fishman M.J. and K.M. Hagerty, 1992, Insider Trading and the Efficiency of Stock Prices, RAND Journal of Economics 23(1), 106-122.

[22] Grullon G. and R. Michaely, 2004, The Information Content of Share Repurchase Programs, Journal of Finance 59(2), 651-680.

[23] Holden C.W. and A. Subrahmanyam, 1992, Long-lived Private Information and Imperfect Competition, Journal of Finance 47, 247-270.

[24] Huddart S., J.S. Hughes and C.B. Levine, 2001, Public Disclosure and Dissimulation of Insider Traders, Econometrica 69, 665-681.

[25] Ikenberry D., J. Lakonishok and T. Vermaelen, 1995, Market underreaction to open market share repurchases, Journal of Financial Economics 39, 181-208.

[26] John K. and R. Narayanan, 1997, Market Manipulation and the Role of Insider Trading Regulations, Journal of Business 70(2), 217-247.

[27] Khanna N., S. Slezak and M. Bradley, 1994, Insider Trading, Outside Search and Resource Allocation: Why Firms and Society May Disagree on Insider Trading Regulation?, Review of Financial Studies 7(3), 575-608.

[28] King M. and A. Roell, 1988, Insider Trading, Economic Policy 6, 163-193.

[29] Kyle A.S., 1985, Continuous Auctions and Insider Trading, Econometrica 53, 1315-1335.

[30] Leland H.E., 1992, Insider Trading: Should it be Prohibited?, Journal of Political Economy $100,859-887$.

[31] Lehn K., 1989, The Economics of Insider Trading, mimeo, International Conference on Insider Trading, University of Rome.

[32] Manove M., 1989, The Harm from Insider Trading and Informed Speculation, Quarterly Journal of Economics, 823-845.

[33] Maug E., 2002, Insider Trading Legislation and Corporate Governance, European Economic Review 46, 1569-1597.

[34] Medrano L.A. and X. Vives, 2004, Regulating Insider Trading when Investment Matters, Review of Finance 8, 199-277.

[35] Miller M. and F. Modigliani, 1961, Dividend Policy, Growth, and the Valuation of Shares, Journal of Business 34, 411-433.

[36] Mitchell M.L. and E. Stafford, 2000, Managerial Decisions and Long-Term Stock Price Performance, Journal of Business 73, 287-329.

[37] Oded J., 2005, Why Do Firms Announce Open-Market Repurchase Programs?, Review of Financial Studies 18(1), 271-300.

[38] OICV-IOSCO, 2004, Report on "Stock Repurchase Programs", International Organization of Securities Commissions.

[39] Peher U.C. and T. Vermaelen, 2005, The Many Facets of Privately Negotiated Stock Repurchases, Journal of Financial Economics 75, 361-395.

[40] Stephens C.P. and M.S. Weisbach, 1998, Actual Share Reacquisitions in Open-Market Repurchase Programs, Journal of Finance 53, 313-334. 


\section{Table 3: Insider trading (IT) and share repurchases (SR) regulations}

This table shows equilibrium information allocations (first row) and aggregate welfare (other rows) associated with securities regulation. The first column highlights the three partitions of the risky asset excess return, generated by short-term shareholders' loss functions. The other columns represent four possible combinations of regulations: $c=1(c=0)$ means that insider trading regulation is (not) enforced. SR regulation indicates a ban on share repurchases. The shaded area represents the partitions of the excess return in which full investment is reached in the market. When only insider trading regulation is enforced, the underinvestment area widens. When both regulations are implemented full investment is attained in every partition.

\begin{tabular}{|c|c|c|c|c|}
\hline \multirow[b]{2}{*}{ IT regulation } & \multirow[b]{2}{*}{$c=0$} & \multirow[b]{2}{*}{$c=1$} & \multicolumn{2}{|c|}{$\mathrm{SR}$ regulation } \\
\hline & & & $c=0$ & $c=1$ \\
\hline Info. Allocation & $c p^{*}=\{0,0\}$ & $c p^{*}=\{1,0\}$ & $c p^{*}=\{0,0\}$ & $c p^{*}=\{0, d\}$ \\
\hline \multirow{2}{*}{$L\left(1,0,0, m^{*}\right)$} & $N^{*} \bar{q}$ & $N^{*} \bar{q}$ & $N^{*} \bar{q}$ & $N^{*} \bar{q}$ \\
\hline & $N^{*} \bar{q}$ & $n^{*} \bar{q}+m^{*}$ & $N^{*} \bar{q}$ & $N^{*} \bar{q}$ \\
\hline$L\left(0,0, n^{*}, m^{*}\right)$ & $n^{*} \bar{q}+m^{*}$ & $n^{*} \bar{q}+m^{*}$ & $n^{*} \bar{q}+m^{*}$ & $N^{*} \bar{q}$ \\
\hline $\bar{q}-1$ & & & & FIRST BEST \\
\hline
\end{tabular}




\section{Table 4: Insider trading (IT) and disclosure regulations}

This table shows the equilibrium information allocation and aggregate welfare when disclosure regulation is combined with a ban on insider trading. The first column highlights the three partitions of the risky asset excess return, generated by short-term shareholders' loss functions. The second one refers to the benchmark case in which no regulation is enforced. The other two columns show the combination between insider trading and disclosure regulation: $c=1(c=0)$ means that insider trading regulation is (not) enforced. The shaded area represents the partitions of the excess return in which full investment is reached in the market. When only disclosure regulation is implemented we obtain the second best allocation.

\begin{tabular}{|c|c|c|c|}
\hline \multirow[b]{2}{*}{ IT regulation } & \multirow[b]{2}{*}{$c=0$} & \multicolumn{2}{|c|}{ Mandated Disclosure } \\
\hline & & $c=0$ & $c=1$ \\
\hline \multirow[t]{2}{*}{ Info. Allocation } & $c p^{*}=\{0,0\}$ & $c p^{*}=\{0, \bar{d}\}$ & $c p^{*}=\{1, \bar{d}\}$ \\
\hline & $N^{*} \bar{q}$ & $N^{*} \bar{q}$ & $N^{*} \bar{q}$ \\
\hline$L\left(1,0,0, m^{*}\right)$ & $N^{*} \bar{q}$ & $N^{*} \bar{q}$ & $N^{*} \bar{q}$ \\
\hline \multirow[t]{2}{*}{$L\left(1, \bar{d}, 0, m^{*}\right)$} & & & \\
\hline & $N^{*} \bar{q}$ & $N^{*} \bar{q}$ & $n^{*} \bar{q}+m^{*}$ \\
\hline \multirow[t]{2}{*}{$L\left(0,0, n^{*}, m^{*}\right)$} & & & \\
\hline & $n^{*} \bar{q}+m^{*}$ & $N^{*} \bar{q}$ & $n^{*} \bar{q}+m^{*}$ \\
\hline$L\left(0, \bar{d}, n^{*}, m^{*}\right)$ & $n^{*} \bar{q}+m^{*}$ & $n^{*} \bar{q}+m^{*}$ & $n^{*} \bar{q}+m^{*}$ \\
\hline $\bar{q}-1$ & & SECOND BEST & \\
\hline
\end{tabular}



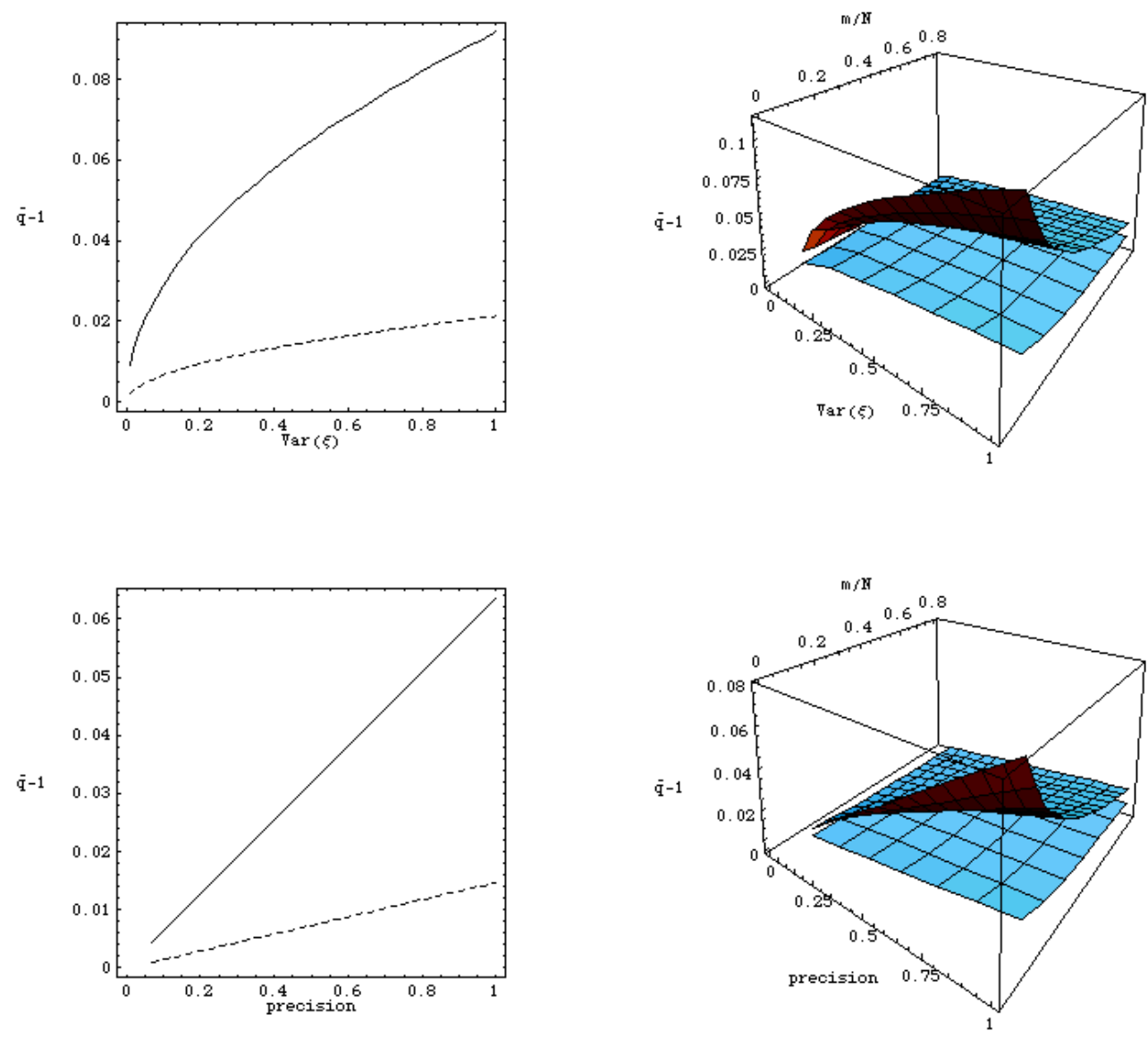

Figure 1: Partitions of the risky asset excess return

These graphs show how the three partitions of the excess return, $\bar{q}-1$, generated by liquidity shareholders' loss functions, respond to variations in liquidity shock variance, $\sigma_{\xi}^{2}$, signal precision, defined as $\sigma_{q}^{2} / \sqrt{\sigma_{q}^{2}+\sigma_{\theta}^{2}}$, and proportion of liquidity shareholders, $m^{*} / N^{*}$. The higher is the variance of liquidity shocks, the higher is the range of the excess return whereby full investment is not reached in the market if insider regulation is enforced. The same relation holds for the signal precision. For the proportion of liquidity shareholders, instead, the relation is reversed: this is so because total adverse selection losses are "paid" by a larger number of shareholders. In the first row of graphs we set $\sigma_{q}^{2}=0.5$ and $\sigma_{\theta}^{2}=0.1$; in the second one $\sigma_{\xi}^{2}=0.2$. 